ISSN: 1838-3815 (online) Journal Homepage: https://ojs.deakin.edu.au/index.php/itlge/

\title{
A professional development program with an assessed ePortfolio: A practical solution for engaging undergraduates with their career development in large student cohorts
}

\author{
Julia K. Choate ${ }^{1}$, Maria Demaria ${ }^{2}$, Michelle Etheve ${ }^{3}$, Sandy $\mathrm{Cran}^{4}$ and David Carroll ${ }^{5}$ \\ Corresponding author: Julia Choate (julia.choate@monash.edu) \\ ${ }^{1}$ School of Biomedical Sciences, Faculty of Medicine, Nursing and Health Science, Monash University, Vic., Australia \\ 2Department of Immunology and Pathology, Central Clinical School, Faculty of Medicine, Nursing and Health Science, Monash \\ University, Vic., Australia \\ ${ }^{3}$ Research Student, The University of Melbourne \\ ${ }^{4}$ Careers Advisor, Ormond College, Parkville, Vic. \\ ${ }^{5}$ Portfolio of the Deputy Vice-Chancellor (Education), Monash University, Vic., Australia
}

\begin{abstract}
Undergraduate biomedical science degree-programs are considered to be non-vocational, with a diverse range of career outcomes. At our university, student and academic feedback indicated that biomedical science students were anxious and uncertain about their career options. In response to this careers anxiety, an in-curriculum, course-wide and assessed professional development program (PDP) was developed and delivered into the biomedical science degree-program by an integrated team of careers educators and biomedical academics. This program aimed to engage a large cohort of biomedical students (>1000) with their career development, improving their careers awareness and reducing their anxiety about careers options. The impacts of the program on students' career and employability skills development, as well as their self-reported levels of psychological distress, were evaluated with on-line anonymous student surveys. Student engagement with the program was linked with program assessment submission rates and student interactions with the University Careers Service. Completion of the program increased students' careers knowledge and confidence, enhanced their awareness of career options and employability skills and increased their engagement with the University Careers Service. It did not alter students' self-reported levels of depression, anxiety and stress, but students who rated themselves poorly on careers awareness and confidence statements were more likely to have severe depression, anxiety and stress. This program provides a practical approach for students' career and employability skills development in large cohorts, but could be expanded to include an intervention to reduce student anxiety.
\end{abstract}

Keywords:

anxiety, biomedical science, career development, eportfolio, graduate employability, undergraduate 


\section{Introduction}

\section{Shifting career aspirations of biomedical science graduates}

Biomedical science degrees were established at Australian universities in the last 20 years to educate and train students to be biomedical researchers. Similar to the long-standing Bachelor of Science degrees, they were considered to be non-vocational with a diverse range of career outcomes. Initially, most students attracted to biomedical degree programs were interested in biomedical research (Harris, 2007; Skatova \& Ferguson, 2014). However, the last 10 years have seen a shift in the career aspirations of students enrolling in biomedical science degrees at Monash University, with up to $70 \%$ of students aiming for graduate medicine (Hodgson, Waring, Flecknoe, \& Choate, 2015). This shift in the career intentions of biomedical students is also evident in recent data from the Quality Indicators of Learning and Teaching (QILT) Graduate Outcomes Survey (2016-2017), which shows that most Biomedical Science graduates at Monash enrol in further full-time study, 53\% higher than for other graduates in 2017 (QILT, 2018). In 2016, 67\% of Monash Biomedical science graduates pursued further studies in Health (including graduate medicine) and $29 \%$ in Natural and Physical Sciences (including research honours in biomedical science) (QILT, 2017). Alongside these changes in career intentions, Monash has experienced increased biomedical student enrolments (from 200 in 2013 to 700 in 2019) and elevated biomedical science student anxiety and uncertainty about their future career pathways following completion of this non-vocational degree (see Choate, Green, Cran, Macaulay, \& Etheve, 2016).

\section{Career aspirations, graduate employability and student wellbeing}

Improving job prospects and enhancing career development is a key focus for students entering higher education, particularly for students undertaking non-vocational degree programs like biomedical science (Gillie \& Gillie, 2003; Kandiko \& Mawer, 2013). This is not surprising, as Australian graduates have higher employment rates (84\% aged 25-64; 2016 data) than high school leavers (78\%; OECD, 2018). This student focus on careers and employability, particularly in non-vocational degrees, is associated with elevated undergraduate stress and anxiety about careers. For example, post-graduation career plans were a key reason for psychological distress for undergraduates attending campus mental health services at a US college (Beiter et al., 2015). Student anxiety and stress about their careers supports the need for careers education in undergraduate non-vocational degree programs. Metaanalyses of the careers outcome literature indicates that engaging students with their career development promotes careers awareness, employability and wellbeing (Brown \& Roche, 2016; Gedye, Fender, \& Chalkley, 2004; Mayston, 2002; Watts \& Hawthorn, 1992; Whiston, Sexton, \& Lasoff, 1998). Indeed, students' career development and mental health are considered interconnected, with career indecision related to depression (Walker \& Peterson, 2012; Zunker, 2008) and lower anxiety levels leading to increased engagement in career preparation processes (i.e. self-efficacy and job search intentions; see Deer, Gohn, \& Kanaya, 2018). Zunker (2008) suggested that as career and mental health concerns are interconnected, they should be treated holistically and not as separate entities.

\section{How to effectively engage undergraduates with their career development}

Undergraduate career development is more likely to be successful if it is in-curriculum, assessed and course-wide (Bridgstock, 2009; Bridgstock, Grant-Imaru, \& McAlpine, 2019). Indeed, in-curriculum undergraduate career development programs have been associated with reductions in unemployment, job-search times and with improved engagement with career development (Ciarocco, 2018; Hughes, Bosley, Bowes, \& Bysshe, 2002; Thomas \& McDaniel, 2004). It is also important to start undergraduate career development early in their degree program, as this will enable students to engage with the development of their career options and employability early, while building skills to manage this. Many

Choate, J., Demaria, M., Etheve, M., Cran, S., \& Carroll, D. (2019). A professional development program with an assessed ePortfolio: A practical solution for engaging undergraduates with their career development in large student cohorts. Journal of Teaching and Learning for Graduate Employability, 10(2), 86-103. 
undergraduate students do not engage with their career planning until they graduate, at which point it can be too late (Perrone \& Vickers, 2003). Programs to engage students with their career development learning should involve an integrated careers educator and academic model (Bridgstock, 2009; Jackson \& Wilton, 2016). This career development model aligns the interests of the university and their students (the 'educational interface'), facilitating individual student engagement (Kahu, 2013; Kahu \& Nelson, 2018) and enabling academics to demonstrate the relevance of their subjects to students (Tinto, 2017). This integrated team is essential, as university careers staff are often isolated from academics and the curriculum. Even where universities provide efficient careers services staffed with expert careers educators, students often fail to engage with the services offered (e.g. workshops, seminars and individual careers advisory sessions) because they are not aware of them, do not have time to engage with them, or do not see their relevance (Bridgstock, 2009).

\section{An in-curriculum, course-wide biomedical science professional development program}

In response to the shift in biomedical student career aspirations at Monash University, together with academic, careers educator and student feedback regarding elevated careers anxiety and uncertainty in the cohort, an in-curriculum professional development program (PDP) was introduced into the biomedical science degree program in 2015 (see Choate et al., 2016) and still continues. The program commences in the first semester of the degree program with five modules scaffolded across core biomedical science subjects over three years (Figure 1). Students are assessed, and receive feedback, on their contributions to an electronic portfolio (ePortfolio), a process that enables them to curate, and reflect on, evidence of their achievements. The program aims to raise students' skills in navigating their own careers, raising their career confidence and giving them a greater sense of control in the face of uncertainty. It relies on biomedical academics and careers staff working together to develop, embed and evaluate an in-curriculum program specifically tailored for the Bachelor of Biomedical Science (BBiomedSc) cohort.

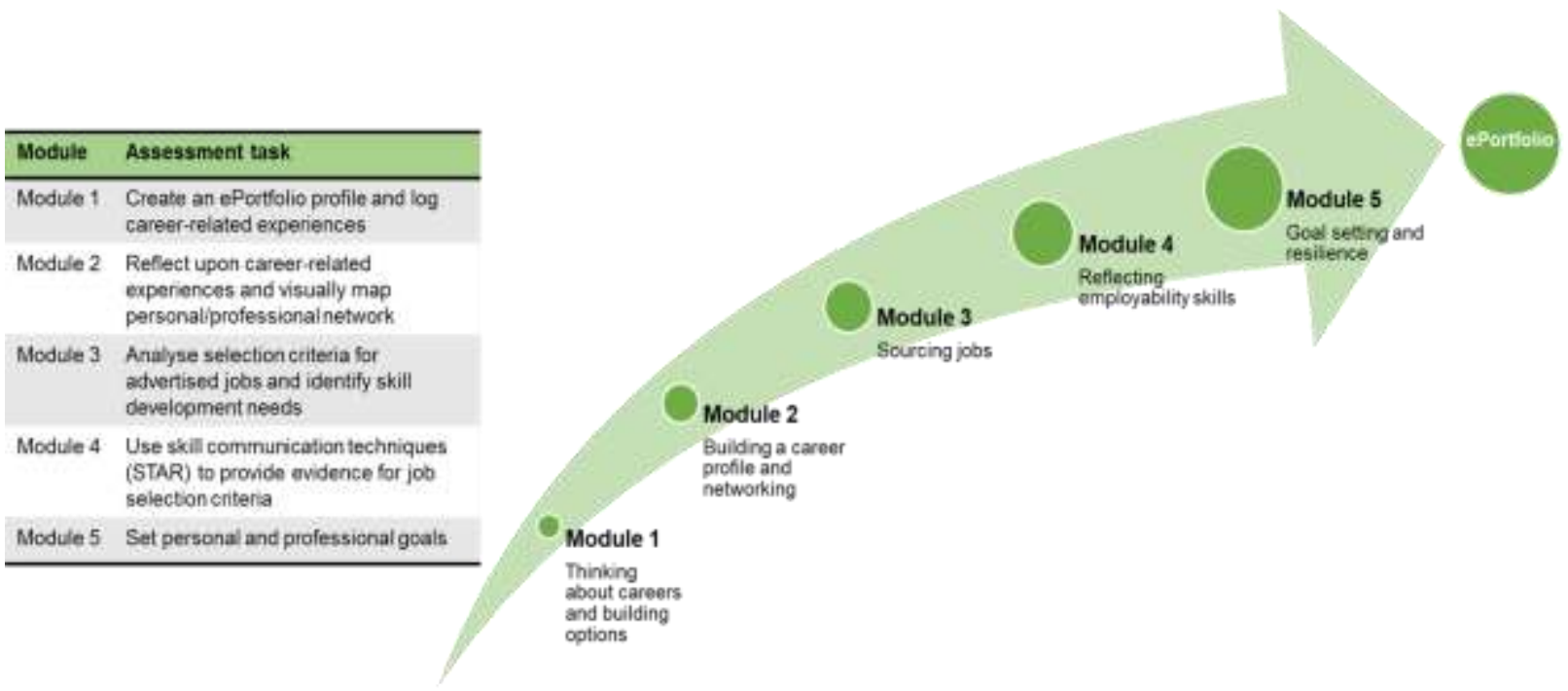

Figure 1: A Summary of the Five Modules of the Professional Development Program, with the Topic of the Module and the Assessment Task (in the table).

Choate, J., Demaria, M., Etheve, M., Cran, S., \& Carroll, D. (2019). A professional development program with an assessed ePortfolio: A practical solution for engaging undergraduates with their career development in large student cohorts. Journal of Teaching and Learning for Graduate Employability, 10(2), 86-103. 
Given the large student cohort in the Monash University Biomedical science degree-program it was essential that the program could be easily taught and administered at scale. The development team considered offering the modules as self-directed on-line modules, but this approach is not as effective as face-to-face delivery from a career development expert (see Whiston, Brecheisen, \& Stephens, 2003). Brown and Ryan Krane (2000) identified five critical ingredients influencing the effectiveness of career interventions: written exercises, individualised interpretations and feedback, information on the world of work, modelling by more competent others and support from social networks. They found interventions that included three or more ingredients were more effective than those that included only one or two. The Monash PDP includes at least three of these ingredients; assessments are written, students get individualised feedback, they gain information about the world of work through guest speakers at the PDP lectures and often these guest speakers become part of the students' networks.

This paper reports on an investigation of the impact of a Professional Development Program on biomedical science students' careers awareness and confidence. We hypothesised that the PDP would enhance students' careers confidence, their engagement with their career development and improve their awareness of potential careers. Since our students were stressed and anxious about their future careers, we also examined the impact of completing the PDP on students' self-reported psychological distress using the Depression, Anxiety, Stress Scales (DASS) (see Lovibond \& Lovibond, 1995). We hypothesised that engaging students with their career development (via the PDP) would reduce their career uncertainty and therefore their anxiety.

\section{Methods}

\section{Research design}

The Professional Development Program was introduced into the first year of a three-year Bachelor of Biomedical Science degree program (BBiomedSci) in 2015, at Monash University, an Australian research-intensive university, and has been running since this time. The aims of this research were to determine if the professional development program: (1) enhanced students' careers awareness and confidence, (2) engaged students with their career development and, (3) reduced their career uncertainty and therefore their anxiety. A mixed methods research approach was used, with quantitative (student careers and wellbeing surveys) and qualitative (open-ended questions on student surveys, focus group discussions) data. The surveys were anonymous and on-line and were used to evaluate the impact of the PDP on students' careers and employability skills awareness (careers survey) and wellbeing (wellbeing survey). Surveys were administered electronically via the online learning system. Students were invited to take the surveys when they submitted their ePortfolio assessment (2015-16) or during weeks 2-4 of the academic year (2017-18).

\section{Careers survey}

The careers survey contained eight career development statements, answered with a five-point Likert scale from strongly disagree to strongly agree. For analysis of this Likert scale data, the responses were allocated values from 1 (strongly disagree) to 5 (strongly agree), then a non-parametric Kruskal-Wallis $\mathrm{H}$ test (i.e. one-way ANOVA on ranks) was used to determine if there were statistically significant differences between the modules for each of the careers statements. The careers survey was also administered across two other Victorian University biomedical science degree-programs. These two other courses had differing degrees of embedded career development (none and a final year industry placement) so this data helped to determine the effectiveness of the Monash University Biomedical Science Professional Development Program.

Choate, J., Demaria, M., Etheve, M., Cran, S., \& Carroll, D. (2019). A professional development program with an assessed ePortfolio: A practical solution for engaging undergraduates with their career development in large student cohorts. Journal of Teaching and Learning for Graduate Employability, 10(2), 86-103. 


\section{Wellbeing survey}

The wellbeing survey used the 21-item Depression, Anxiety and Stress Scale (DASS) to estimate levels and forms of psychological distress associated with poor mental health. The DASS assesses the severity of symptoms associated with depression, anxiety and stress (see Lovibond \& Lovibond, 1995). Scores on the DAS scales are categorised into five categories (normal, mild, moderate, severe and extremely severe) and indicate the level of severity of relevant symptoms for the week before the students complete the survey. DASS scores for each category were calculated according to the protocols in the DASS manual (Lovibond \& Lovibond, 1995). Survey respondents were excluded from a DAS scale if they had not completed all of the statements for a scaling (as all statements are required for the calculations). Information about counselling and support services available to students experiencing mental health difficulties was included in the Explanatory statement provided to students and in the survey.

To test the relationship between students' responses to the eight careers statements (in the careers survey) and their levels of psychological distress (as assessed with the wellbeing survey), a series of pairwise two-proportion Z-tests were conducted to compare the proportions of students indicating agreement with a particular career statement (strongly agree and agree), across three levels of each DASS domain. For example, the proportions indicating agreement and moderate/severe or extremely severe stress were separately compared with the proportion indicating agreement and normal or mild stress.

\section{Qualitative written comments and focus groups}

Open-ended questions were also used to investigate 'What aspects of the program could be improved?' and 'What were the best aspects of this program?' Qualitative written comments were collated and grouped into major themes by an independent administrator. A person independent of the degreeprogram facilitated student focus group discussions. These focus groups were designed to provide more detailed feedback about the PDP.

\section{Assessment submission rates and student attendance at the University Careers Service}

The average module assessment submission rates were collated (as an indicator of student engagement with the program and their career development) and after module 1 in 2017 students who did not submit their assessment were invited to complete a voluntary and anonymous survey about why they did not submit their assessment. Biomedical science student engagement with the University Careers Service was tracked, by the Careers Service, using Career Hub software.

\section{Analysis software and ethics}

Graphpad Prism 7 was used for statistical analysis (careers statements) and graphing, with SPSS 25 used for data and statistical analysis of the DASS data and for testing the correlation between the careers statements and the DASS results. This research was approved by the Monash University Human Research Ethics Committee (\#2015-6135-5964; Impact of a Professional Development Program on Monash University biomedical student careers awareness and wellbeing \#2018-7753-16790; An evaluation of students career intentions, careers confidence and careers awareness across Victorian university biomedical degree-programs).

\section{Results}

Completion of the program modules was associated with enhanced students' self-rating of their careers awareness and knowledge, with large increases in biomedical student engagement with the offerings of the University Careers Service and with students sourcing current advertised jobs that did not align with

Choate, J., Demaria, M., Etheve, M., Cran, S., \& Carroll, D. (2019). A professional development program with an assessed ePortfolio: A practical solution for engaging undergraduates with their career development in large student cohorts. Journal of Teaching and Learning for Graduate Employability, 10(2), 86-103. 
their immediate career intentions. Anonymous student feedback indicated that they understood the intentions and aims of the program; they felt that the program engaged them with their career development and made them aware of diverse career options. Despite engaging with their career development, students self-reported psychological distress levels did not change as they completed the PDP modules. However, a significant correlation was found between students with high levels of selfreported psychological distress (i.e. severe and extremely severe depression and anxiety) and low levels of agreement with the career development statements.

\section{Student engagement with the program as related to high completion and assessment submission rates}

Making the PDP in-curriculum and assessed should increase student engagement, compared to extracurricular programs. In total, 3,054 students have commenced the program, with 824 having completed all five modules, and the remainder having completed between two and four of the five PDP modules. The students submitted the PDP assessments at high rates $(89.4 \pm 1.2 \%$ across 14 modules from 2015-2018; mean \pm SEM). They appreciated that the PDP modules were assessed. Written student comments from the anonymous survey included:

The assessment made me sit down and actually think about it [i.e. my career development]. I actually did a lot of work.

Assessments gave me the motivation to do it - more [assessments] throughout might be more helpful (e.g. two per semester).

After module 1 in 2017, the students ( $n=46$ ) who did not submit the PDP assessment were emailed an anonymous survey in order to ascertain their reasons for non-submission. Of concern, $67 \%$ selected ' didn't know I had to complete an assessment task for this module', as this suggests that they had not engaged with the program, either via their on-line subject management system or via attending the PDP lecture. Another $24 \%$ of non-submitting students selected 'I didn't have time - I had other assessments which were a priority'.

\section{A job searching assessment exercise and guest speakers enhanced students' careers awareness and confidence}

To encourage students to expand their career awareness, the module 3 assessment required them to source currently advertised jobs. Figure 2 compares the advertised jobs the students selected for module 3 in 2016-18 with the career intentions of these students. In 2018, students were asked to rate their confidence in their career intentions (from 1= Extremely unconfident; 2 = Unconfident; 3 = Neutral; $4=$ Confident and $5=$ Extremely confident), rather than ranking their top career intentions from 1-5 as was done in 2016-17. When the year 2 students rated their confidence in pursuing selected careers, $32 \%$ were confident or extremely confident that they would pursue a career in medicine, with $9 \%$ for research and 19\% for further graduate studies in allied health ( $n=114 ; 24 \%$ response rate). Taken together, these data demonstrate that by engaging in this PDP module students are looking at jobs other than those that align with their immediate career intentions and hence the PDP is broadening their career awareness.

Choate, J., Demaria, M., Etheve, M., Cran, S., \& Carroll, D. (2019). A professional development program with an assessed ePortfolio: A practical solution for engaging undergraduates with their career development in large student cohorts. Journal of Teaching and Learning for Graduate Employability, 10(2), 86-103. 


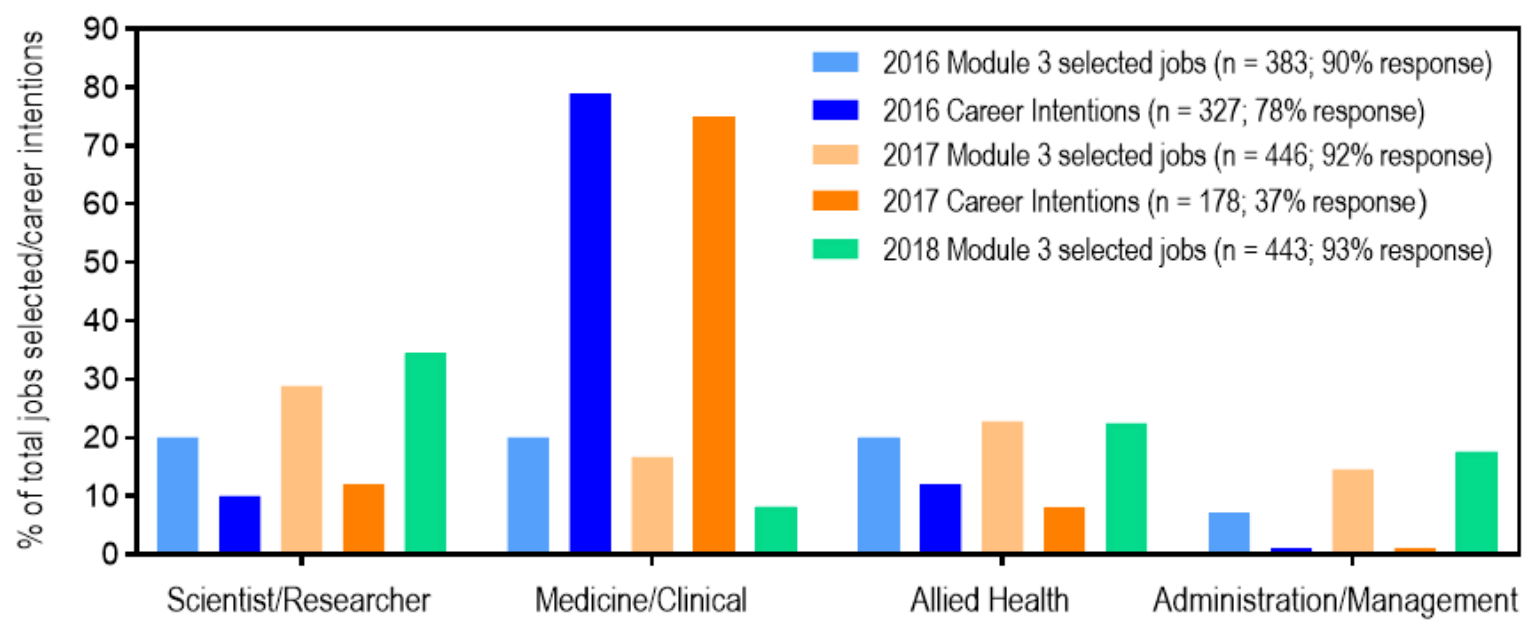

Figure 2: Top-rated Career Intentions of Students (determined from the careers survey; darker colours) and the Jobs they Selected for Module 3 of the Professional Development Program (lighter colours), Sorted into the Major Types of Careers/Jobs

In order to expand students' awareness of their post-biomedical science career options, the program modules include guest speakers, including Monash University biomedical science alumni, Monash University graduate course coordinators and external guests (see Table 1). Student feedback suggests that these speakers lead to improved careers awareness and confidence. This is evident from the students' written comments on the careers survey, including:

Hearing the stories of previous students and being able to relate to them. It gives us an idea of some of the things we ourselves can do. Knowing what employers want is also another aspect that was very useful.

I really like hearing about other people's' experiences and how they thought when they were in our position.

Table 1: A Summary of Guest Speakers from the Biomedical Science (BMS) Professional Development Program Lectures (2015-18)

\begin{tabular}{|l|l|}
\hline Type of speaker & Career focus or pathway \\
\hline BMS alumni & $\begin{array}{l}\text { Graduate medicine, Masters in Nursing, PhD student, Masters in Secondary } \\
\text { Teaching, Monash Entrepreneurship Program (The Generator), Consultant at } \\
\text { Deloitte, Associate at PwC }\end{array}$ \\
\hline $\begin{array}{l}\text { Monash course convenors } \\
\text { and advisors }\end{array}$ & $\begin{array}{l}\text { Pharmacy/Pharmaceutical Sciences, Nursing, Reproductive Health, Graduate } \\
\text { Medicine }\end{array}$ \\
\hline External speakers & $\begin{array}{l}\text { Secondary Teaching, Cardiac Technology, Respiratory Physiology, } \\
\text { Pharmaceutical Industry (Director at CSL), Intensive Care Specialist }\end{array}$ \\
\hline
\end{tabular}

Additional benefits from students meeting these speakers, especially those from non-medical careers, include being provided with work experience opportunities and more defined career goals. Examples include two students completing work experience in cardiac technology and students enrolling in the

Choate, J., Demaria, M., Etheve, M., Cran, S., \& Carroll, D. (2019). A professional development program with an assessed ePortfolio: A practical solution for engaging undergraduates with their career development in large student cohorts. Journal of Teaching and Learning for Graduate Employability, 10(2), 86-103. 
Monash University Masters Courses in Clinical Embryology and Pharmacy. Student comments from focus group discussions:

One of my friends, when she learnt about the Monash IVF program [from the invited speaker], she fell in love with it and now that's what she is keen on.

Similarly, the pharmacy course advisor prompted a student to follow this career path:

I will definitely pursue a career in Pharmacy after hearing [invited speaker] talk.

\section{Completion of the program enhanced students' responses to career development statements}

Figure 3 shows that there were significant increases in the students self-ratings for 7 of the 8 career development statements between years 1,2 and year 3, supporting the idea that completion of the program modules engages students with their career development. This careers survey was administered across two other Victorian undergraduate biomedical degree-programs (University 2 has no careers program; University 3 has industry placements in year 3 ). Results showed that only Monash University students enhanced their career development from year 1 to year 3 of the degree program, suggesting that engagement with the PDP is a contributing factor (Figure 4).

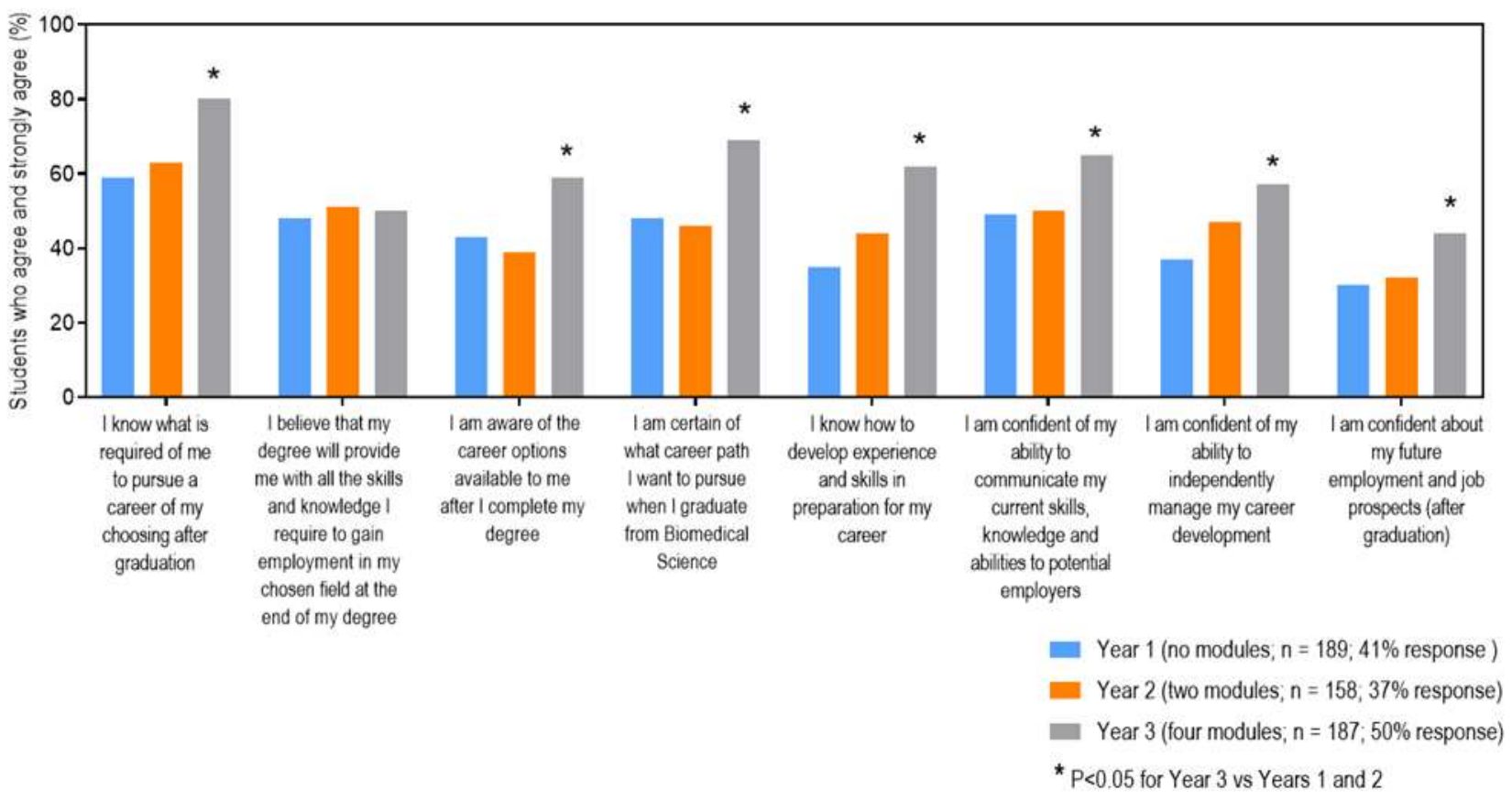

Figure 3: The \% of Students in Years 1, 2 and 3 Who Agreed and Strongly Agreed with Eight Career Development Statements (2017 data). (Year 1 Students had not completed any of the Professional Development Program modules, Year 2 students had completed modules 1 and 2 and Year 3 students had completed modules 1 to 4)

Choate, J., Demaria, M., Etheve, M., Cran, S., \& Carroll, D. (2019). A professional development program with an assessed ePortfolio: A practical solution for engaging undergraduates with their career development in large student cohorts. Journal of Teaching and Learning for Graduate Employability, 10(2), 86-103. 


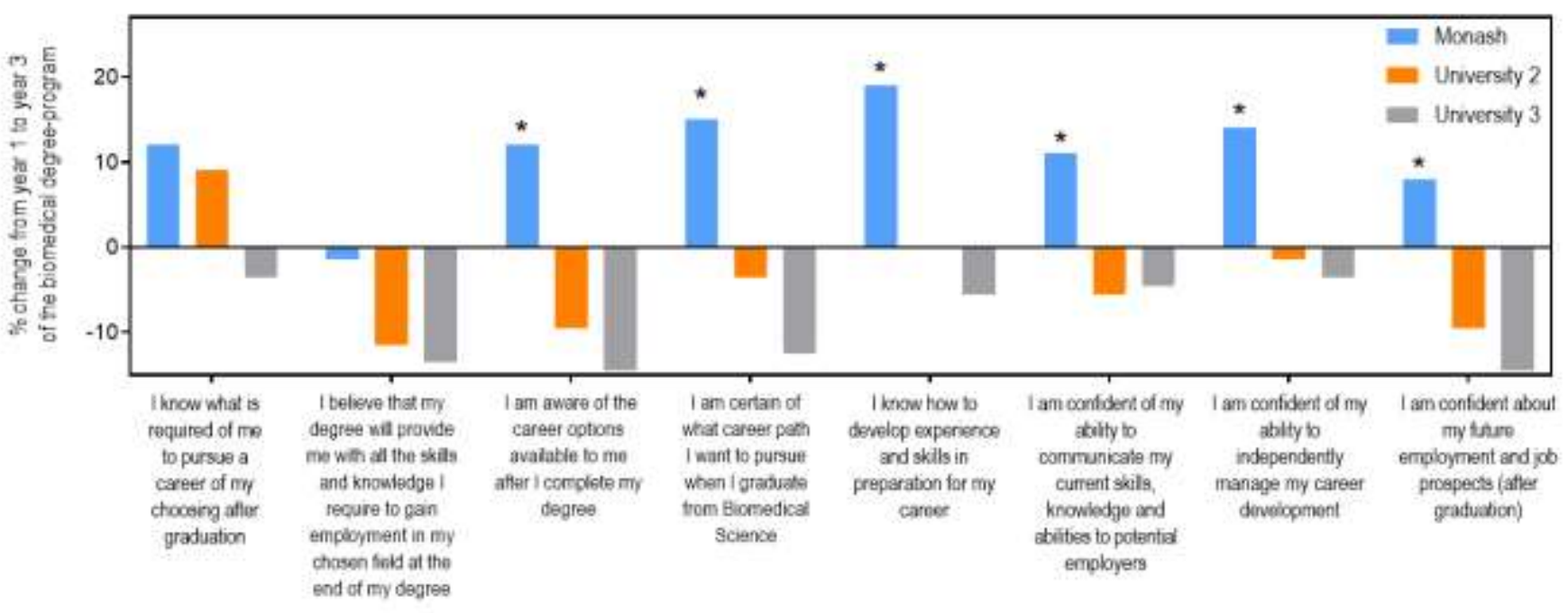

Figure 4: Responses to Eight Careers Statements from Students Enrolled in Undergraduate Biomedical Science Degree-Programs at Three Victorian Universities (expressed as a \% change from year 1 to year 3) (2017 data). (Monash: $n=596,43 \%$ Response across years 1 and 3; University 2: $n=159,24 \%$ Response; University 3: $n=268,18 \%$ Response). $\left({ }^{*} P<0.05\right)$.

\section{Enhanced student engagement with the University Careers Service since the introduction of the Professional Development Program}

The University has a centralised Careers Service, although this model changed at the end of 2017. Students can book 30-minute one-on-one sessions with a careers education consultant, drop-in for a 10-minute career chat or they can attend and participate in careers workshops or industry networking events. The Careers Service keeps records of the students who participate in these sessions. Since the introduction of the program in 2015, there has been a significant increase in biomedical student interactions with Monash Careers, Leadership and Volunteering (Figure 5). These data, together with qualitative student feedback (comments below), supports the value of the PDP in enabling students to be proactive in their own career development.

Students in the focus groups commented that they appreciated the careers service:

I now know what services are available to support me in pursuing a career after completing my degree and finding a job while studying.

It was good to know that there is a team that I can talk to and discuss career related issues/problems that may arise during my studies.

At the end of 2017, the University Careers Service changed its delivery model and restructured, such that there are no longer individual one-on-one appointments, but rather online review services, drop-in question sessions and group workshops. There was also no longer a careers advisor responsible for the in-curriculum support and delivery of biomedical careers development. Figure 6 shows undergraduate biomedical student engagement with the University Careers Service in the first quarter of 2018. The group interactions/workshops are not unique student numbers, and many students attended multiple workshops. Despite the modified offerings, it is clear that the numbers of biomedical students engaged with the Careers Service has decreased.

Choate, J., Demaria, M., Etheve, M., Cran, S., \& Carroll, D. (2019). A professional development program with an assessed ePortfolio: A practical solution for engaging undergraduates with their career development in large student cohorts. Journal of Teaching and Learning for Graduate Employability, 10(2), 86-103. 

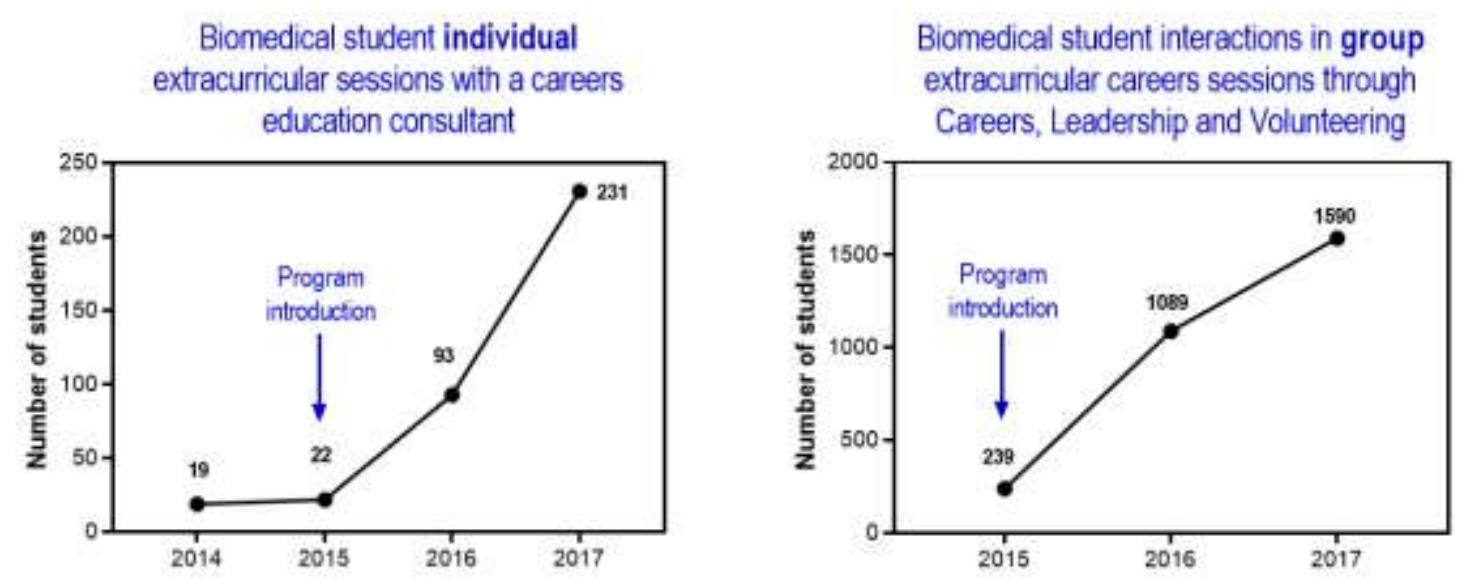

Figure 5: The Number of Biomedical Science Students Attending Appointments with a Careers Consultant (left hand side) or Group Events Organised by Careers Leadership and Volunteering (right hand side) between the start of 2014 and the end of 2017. (The Professional Development Program was introduced into the biomedical curriculum at the start of 2015.)
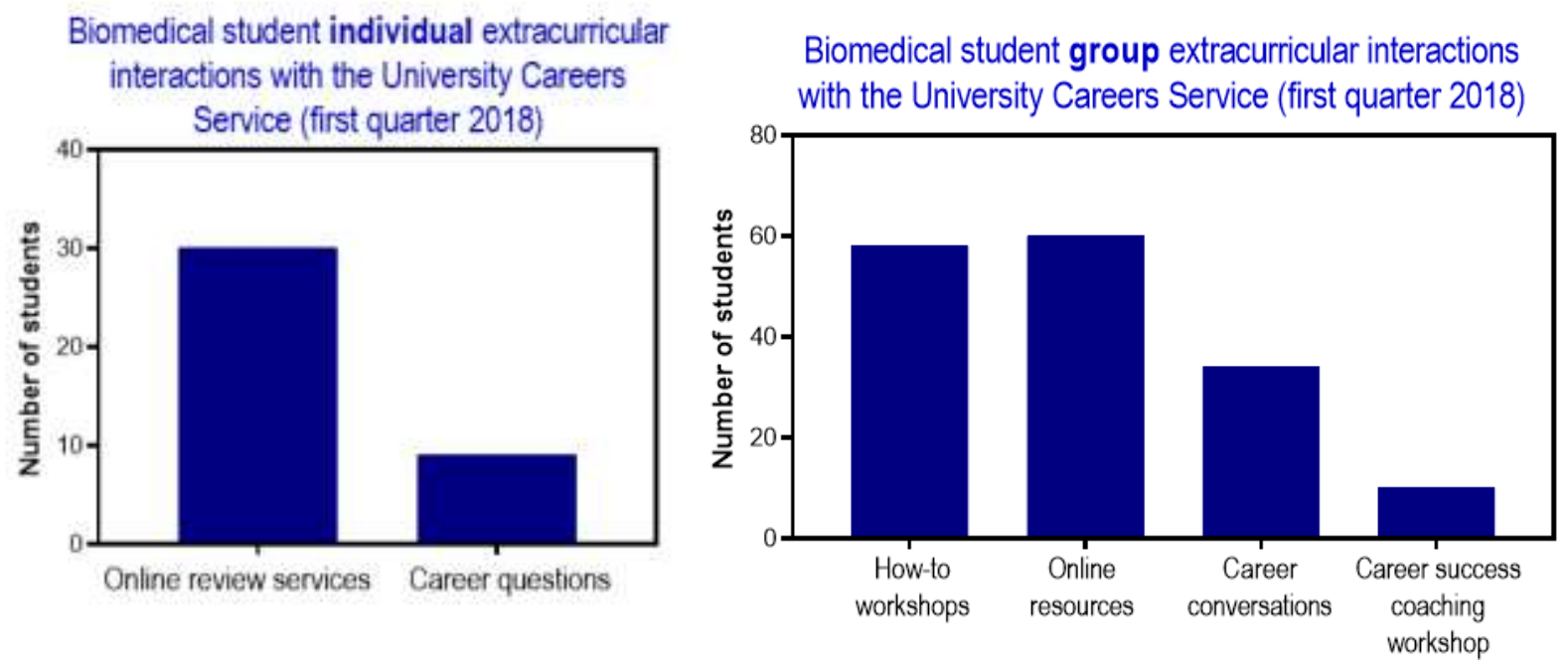

Figure 6: The Number of Biomedical Science Students Interacting with the New Offerings of the University Careers Service in the First Quarter of 2018. (Individual services are shown on the left and group services on the right.)

\section{Students written comments suggested that the Professional Development Program engaged them with their career development}

Students who completed program modules 1 to 4 in 2016 provided anonymous written feedback about the best aspects of the program and improvements they felt could enhance the program (Tables 2 and 3). About a third of the students who provided feedback felt that the program encouraged them to think about career planning, with about $10 \%$ of first year students (i.e. modules 1 and 2) indicating they felt that it made them think about careers early in their degree (Table 2, column 4). Between 5-12\% mentioned that the program made them think about non-medical careers.

Student written comments in response to 'What were the best aspects of this program?' included:

Choate, J., Demaria, M., Etheve, M., Cran, S., \& Carroll, D. (2019). A professional development program with an assessed ePortfolio: A practical solution for engaging undergraduates with their career development in large student cohorts. Journal of Teaching and Learning for Graduate Employability, 10(2), 86-103. 
I believe that the introduction of a program like this was sorely needed by students today, as navigating the job market, and more importantly, gaining skills before you enter it is a daunting and often confusing task.

Forced me to independently take responsibility in thinking about my future career, and what actions to take to improve myself.

This program pushed me to actually think about a career path outside of medicine. It allowed for me to explore and plan for life after graduation.

Hearing from people that had completed Biomed degrees and are in a range of different professions now.

Having people come in from industry and speak about their work is a good way of getting multiple perspectives.

Table 2: Main Themes of Students' Written Responses to the Question: 'What were the Best Aspects of this Program?' (2016; expressed as a \% of total student comments)

\begin{tabular}{|c|c|c|c|c|c|c|}
\hline & $\begin{array}{l}\text { Career } \\
\text { planning }\end{array}$ & $\begin{array}{l}\text { Providing non- } \\
\text { medicine careers } \\
\text { options } \\
\end{array}$ & $\begin{array}{c}\text { Thinking } \\
\text { about careers } \\
\text { early } \\
\end{array}$ & $\begin{array}{l}\text { Professional } \\
\text { skill } \\
\text { development }\end{array}$ & $\begin{array}{c}\text { Examples of } \\
\text { different } \\
\text { speakers } \\
\end{array}$ & $\begin{array}{c}\text { Useful } \\
\text { information }\end{array}$ \\
\hline $\begin{array}{l}\text { Module } 1 \\
\text { ( } n=331 ; 60 \% \text { Response) }\end{array}$ & $27 \%$ & $5 \%$ & $8 \%$ & $13 \%$ & $5 \%$ & $28 \%$ \\
\hline $\begin{array}{l}\text { Module } 2 \\
\text { ( } n=216 ; 42 \% \text { Response) }\end{array}$ & $32 \%$ & $12 \%$ & $10 \%$ & $5 \%$ & $3 \%$ & $16 \%$ \\
\hline $\begin{array}{l}\text { Module } 3 \\
\text { ( } n=204 ; 48 \% \text { Response) } \\
\text { Module } 4\end{array}$ & $40 \%$ & $10 \%$ & $2 \%$ & $5 \%$ & $6 \%$ & $24 \%$ \\
\hline ( $n=148 ; 36 \%$ Response) & $30 \%$ & $8 \%$ & $2 \%$ & $11 \%$ & $9 \%$ & $22 \%$ \\
\hline
\end{tabular}

When asked how the program could be improved, between $9-29 \%$ of the students responses were about the provision of more specific career options specifically related to biomedical science. The other common themes for these comments included ensuring that the module assessment did not clash with other assessments in their core subjects, modifying the assessment activities so they were more realistic (e.g. writing a cover letter), providing workplace or volunteer opportunities, more lecture time or one-on-one sessions for the program and making these sessions more hands-on and interactive (Table 3).

Student written comments in response to 'What aspects of the program could be improved?' included:

A mentor provided to groups of people who could help to develop and explore ideas for students in their group, providing a more guided and individual experience for this task.

Maybe a face to face support will be better. The students discussing their careers with professionals is a great idea.

I think the cohort would benefit from a wellbeing program alongside The Professional Development Program.

Choate, J., Demaria, M., Etheve, M., Cran, S., \& Carroll, D. (2019). A professional development program with an assessed ePortfolio: A practical solution for engaging undergraduates with their career development in large student cohorts. Journal of Teaching and Learning for Graduate Employability, 10(2), 86-103. 
Table 3: Main Themes of Students' Written Responses to the Question: 'What Aspects of the Program could be Improved?' (2016; \% of total student comments)

\begin{tabular}{|l|cccc|}
\hline & $\begin{array}{c}\text { The timing and } \\
\text { relevance of } \\
\text { the assessment }\end{array}$ & $\begin{array}{c}\text { Provide more specific } \\
\text { career options related } \\
\text { to biomedical science }\end{array}$ & $\begin{array}{c}\text { Make the } \\
\text { module more } \\
\text { interactive }\end{array}$ & $\begin{array}{c}\text { Provide more specific } \\
\text { real life opportunities }\end{array}$ \\
\hline $\begin{array}{l}\text { Module 1 } \\
\text { (n=270; 49\% Response) } \\
\text { Module 2 } \\
\text { (n=205; 39\% Response) }\end{array}$ & $10 \%$ & $29 \%$ & $17 \%$ & $5 \%$ \\
$\begin{array}{l}\text { Module 3 } \\
\text { (n=190; 45\% Response) } \\
\text { Module 4 } \\
\text { (n=137; 33\% Response) }\end{array}$ & $10 \%$ & $16 \%$ & $11 \%$ & $5 \%$ \\
\hline
\end{tabular}

The Professional Development Program did not impact on students' self-reported levels of psychological distress

The percentage of students self-reporting severe or extremely severe depression, anxiety or stress, according to the DAS Scale analysis is shown in Table 4. Despite the PDP engaging students with their career development, there were no significant changes in these levels as students completed more of the PDP modules, nor as they progressed from year 1 to year 3 of the degree-program. There was, however, a relationship between students' responses to the eight careers statements and their levels of psychological distress, with students' who self-reported severe depression, anxiety and stress significantly less likely to agree with the careers statements than students who self-reported normal or moderate depression, anxiety and stress (Table 5).

Table 4: Students with Self-Rated Severe and Extremely Severe Depression, Anxiety or Stress in Year 1 (Modules 1 and 2), Year 2 (Modules 3 and 4) and Year 3 (Module 5), (expressed as the mean \pm standard error of the mean).

\begin{tabular}{|l|ccc|}
\hline & $\begin{array}{c}\text { DEPRESSION (\% } \\
\text { severe \& extremely } \\
\text { severe) }\end{array}$ & $\begin{array}{c}\text { ANXIETY (\% severe \& } \\
\text { extremely severe) }\end{array}$ & $\begin{array}{c}\text { STRESS (\% severe \& } \\
\text { extremely severe) }\end{array}$ \\
\hline Year 1 (2015-18) & $13.5 \pm 0.4$ & $18.3 \pm 2.7$ & $10.5 \pm 0.8$ \\
Year 2 (2016-18) & $14.8 \pm 2.0$ & $18.8 \pm 2.2$ & $12.8 \pm 1.8$ \\
Year 3 (2017-18) & $15.0 \pm 1.0$ & $22.0 \pm 2.0$ & $16.0 \pm 2.0$ \\
\hline
\end{tabular}

Choate, J., Demaria, M., Etheve, M., Cran, S., \& Carroll, D. (2019). A professional development program with an assessed ePortfolio: A practical solution for engaging undergraduates with their career development in large student cohorts. Journal of Teaching and Learning for Graduate Employability, 10(2), 86-103. 
Table 5: The \% of Students who Responded to the Career Development Statements with 'Agree' or 'Strongly agree' and their Self-Rated Depression, Anxiety and Stress Levels. (All shaded values are significantly different $(P<0.05)$ relative to 'Normal' levels of psychological distress, according to a $Z$ score analysis.) ( $n=573 ; 40 \%$ Response rate).

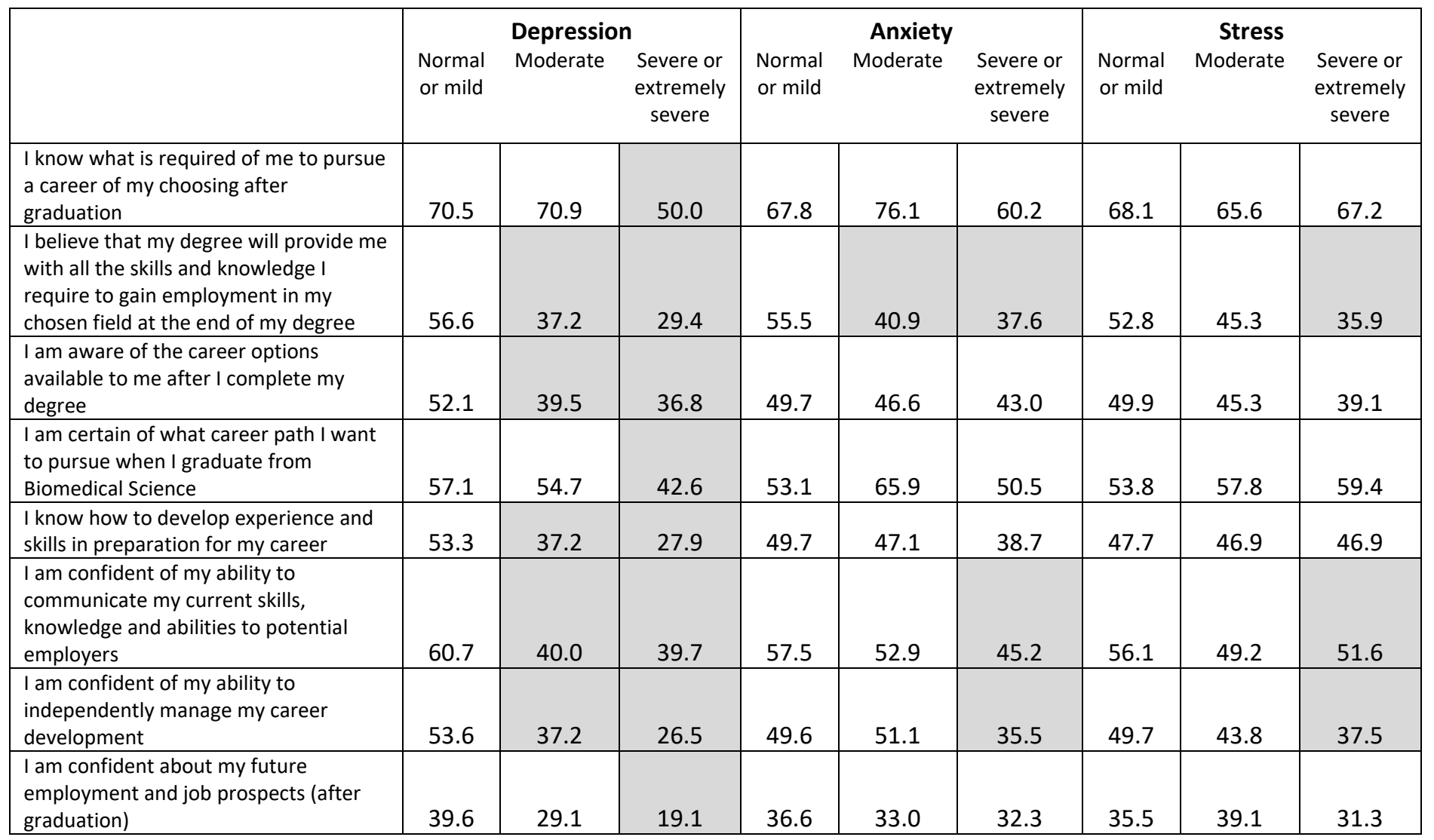

\section{Discussion}

This research found that completion of the Biomedical Professional Development Program modules was associated with enhanced students' careers awareness and engagement with their career development. Whilst students self-reported psychological distress levels did not change as they engaged with their career development by completing the PDP modules, a significant correlation was found between students with self-reported psychological distress and poor responses to the career development statements. This supports the idea that students' career development and mental health concerns are interconnected.

\section{Do other undergraduate in-curriculum career development programs enhance students' career awareness and engagement with their career development?}

There are limited published studies of undergraduate in-curriculum career development programs and their impacts on students' career awareness or employability, and even less that focus on nonvocational degrees (Bridgstock et al., 2019). In a 2018 review of published in-curriculum approaches to career preparation and professional development for US undergraduate psychology majors, it was reported that they lead to students having a better understanding of psychology-related careers, are more knowledgeable about how to access career information and are more likely to exhibit career information seeking behaviour (Ciarocco, 2018). However, unlike the Monash course-wide program, many of these psychology in-curriculum career preparation approaches were limited to single subjects,

Choate, J., Demaria, M., Etheve, M., Cran, S., \& Carroll, D. (2019). A professional development program with an assessed ePortfolio: A practical solution for engaging undergraduates with their career development in large student cohorts. Journal of Teaching and Learning for Graduate Employability, 10(2), 86-103. 
and/or were only embedded into the final year of the degree-program. Our in-curriculum program also improved students' careers awareness through the guest speakers and the job searching assessment and increased student engagement with the University Careers Service. At East Tennessee State University, they embedded a compulsory Career Exploration course into the first three years of their graduate medical degree-program, in order to enhance the career preparedness of their medical students. They reported that the program was successful in helping students with their career decisions based on high student attendance/participation and students self-rated satisfaction with the career planning activities (Olive, Kwasigroch, Wooten, Lybrand, \& Peeples, 2016). However, these factors are not necessarily indicative of students engaging with their career development (see Ciarocco, 2018).

\section{Students' perceptions of their skills and knowledge development during their degree- program}

There was no improvement in the students' self-ratings from year one to year three for the careers statement 'I am confident that my degree will provide me with all the skills and knowledge I require to gain employment in my chosen field at the end of my degree' (see Figures 3 and 4). It may be that students realise by third year that there are skills required for employment beyond those they develop in their biomedical science degree-program, which is an attitude we hoped to develop during the PDP (i.e. that they would take ownership of their career development). To rate this very highly would have been an unrealistic expectation, as job selection criteria ask for skills that could only have been developed with a broad range of experiences, such as extracurricular activities. The students' responses to this statement highlights the deficit in some employability skills within undergraduate degreeprograms and the need for students to develop these skills in work-related experiences during their course, such as work integrated learning (see Bennett, Richardson, \& MacKinnon, 2016; Ferns, Smith, \& Russell, 2014). Most final year students indicated that they 'know how to develop experience and skills in preparation for my career' and they were 'confident about my future employment and job prospects (after graduation)' at significantly higher rates than students in years one and two (see Figure 3). As this effect was not seen for the final year students at the two other Victorian Universities (with no incurriculum professional development program; see Figure 4), this suggests that our program enhances our students engagement with their career development.

\section{The program is a practical approach for engaging large cohorts of students' with their career development in a non-accredited undergraduate degree-program}

This program has been associated with large numbers of students $(2,334)$ completing at least two modules of the program, with an $89.4 \%$ average assessment submission rate and increased student interactions with the University Careers Service, highlighting that it successfully engages students in large cohorts with their career development. It could be easily adapted for use in other undergraduate degree-programs. However, potential adopters of this program need to consider the minimum staffing requirements, including a qualified careers educator and sufficient teaching associates for marking the assessments.

\section{Student engagement with the University Careers Service; the need for a dedicated biomedical careers person and for structured interactions between the careers service and the curriculum}

It is likely that the 2018 decrease in student numbers engaging with the careers service is a result of careers staff no longer dedicated to the biomedical science degree-program, and the ceasing of one-onone career consultations, as had occurred in previous years. It is also worth considering the need for a dedicated careers advisor employed by the faculty to provide a career development role for Biomedical science students (see student comments referring to the need for one-on-one career advice). This suggestion also aligns with research which asserts that interventions facilitated by a career

Choate, J., Demaria, M., Etheve, M., Cran, S., \& Carroll, D. (2019). A professional development program with an assessed ePortfolio: A practical solution for engaging undergraduates with their career development in large student cohorts. Journal of Teaching and Learning for Graduate Employability, 10(2), 86-103. 
development expert are more effective than self-directed or computer-mediated interventions (see Brown \& Ryan Krane, 2000; Whiston et al., 2003; Whiston \& James, 2013; Whiston, Li, Goodrich, Mitts, \& Wright, 2017). In order to increase student engagement with the careers service, workshops from the new modified offerings are being incorporated into the PDP to highlight the value of participating in such offerings to students.

\section{Biomedical science students showed high self-reported levels of psychological distress, but this was not altered by engagement with the PDP}

The average students' self-rated scores for depression $(14 \%$ with severe or extremely severe depression), anxiety (19\%) and stress (12\%) on the DASS-21 scales (see Table 4) were similar to those reported for a 2014 study of 4,258 Australian university students across six undergraduate and graduate degree-programs (including biomedical science) at the University of Melbourne; 13\% for depression, $18 \%$ for anxiety and $13 \%$ for stress (see Larcombe et al., 2016). Larcombe et al. (2016) compared their DASS-21 results with previous studies and found that their university students had higher levels of depression, anxiety and stress than age-matched samples from the general population (see Crawford, Cayley, Lovibond, Wilson, \& Hartley, 2011) and similar levels of self-rated psychological distress as Australian students at other universities (see Rosenthal, Russell, \&Thomson, 2008; Townes, Tang, \& Hall, 2011).

Despite the enhanced awareness of career options, engagement with career development and increased levels of agreement with the careers statements in the survey, there was no reduction in student anxiety levels (as reported in the DASS) as hypothesised. Rather, there was a tendency for the levels of anxiety and stress of students to increase from their first to their third year of study. This effect was also observed (and was significant) for Larcombe et al. (2016). You would expect anxiety and stress levels to increase as students near completion of their degree-program need to clarify the next step in their career pathway.

As higher anxiety levels are associated with lower student engagement with their career development, it is surprising to see that despite students' rising anxiety levels, the PDP has aided in the increase of career awareness and career development. This further highlights the benefits of an in-curriculum program to encourage and support career development over the duration of the students' degreeprogram. Additionally, a direct intervention to reduce student anxiety levels may further improve student engagement with their career development. There are plans to incorporate wellbeing development into the existing professional development program, which may facilitate reductions in anxiety levels and in turn further increase career development engagement.

Acknowledging and addressing the uncertainty and challenges of students career development during the biomedical science degree-program, and having students engage in activities such as job searching that can highlight job scarcity or the demanding criteria of desired jobs, may play a role in the increased levels of anxiety in those students who are less aware of career-related challenges and do not engage in career development or seek to learn the criteria for desired job opportunities until after graduation.

\section{Limitations and future directions}

In order to ascertain the impact of the PDP on students' employability, we would need to track the employment outcomes of our biomedical science graduates. As indicated by Bridgstock (2009) the literature to date lacks systematic investigations into the links between career management competence and long-term graduate employability (p. 40). We have tracked Monash graduate employability via the government outcomes surveys (GOS) that commenced in 2015 (we have the 2016 and 2017 GOS survey data). However, in 2016 the Monash biomedical science response rate was poor.

Choate, J., Demaria, M., Etheve, M., Cran, S., \& Carroll, D. (2019). A professional development program with an assessed ePortfolio: A practical solution for engaging undergraduates with their career development in large student cohorts. Journal of Teaching and Learning for Graduate Employability, 10(2), 86-103. 
In response to biomedical science student feedback on the PDP, requesting work experience and industry engagement, a new work integrated learning (WIL) elective subject was developed and commenced in semester 2, 2018, with industry placements for up to 50 biomedical science students. It is hoped that this subject will be expanded so that 100 single degree biomedical science students can take placements (about one third of this cohort; double degree students have industry placement experiences in their non-biomedical science degree-program).

\section{Acknowledgements}

This project was supported by a Monash University Better Teaching, Better Learning grant and Julia Choate is supported by a Monash Education Academy Fellowship. We would like to thank Brooke Huuskes and Kim Catania for their administrative assistance with the program and the Biomedical science course convenor, course management committee and course advisory board for their ongoing support, including payment of markers, for the program. We would also like to thank all of the students who have completed the Professional Development Program modules and participated in this research project.

\section{References}

Beiter, R., Nash, R., McCrady, M., Rhoades, D., Linscomb, M., Clarahan, M., \& Sammut, S. (2015). The prevalence and correlates of depression, anxiety, and stress in a sample of college students. Journal of Affective Disorders, 173, 90-96. doi: 10.1016/j.jad.2014.10.054

Bennett, D., Richardson. S., \& MacKinnon, P. (2016). Enacting strategies for graduate employability: How universities can best support students to develop generic skill Part A. Canberra, ACT: Australian Government, Office for Learning and Teaching, Department of Education and Training. [last accessed 2019 Mar 29]. Available from: http://www.olt.gov.au/project-how-universities-can-best-support-students-develop-generic-skillsenactingstrategies-gradua

Bridgstock, R. (2009). The graduate attributes we've overlooked: Enhancing graduate employability through career management skills. Higher Education Research \& Development, 28(1), 31-44. doi: 10.1080/07294360802444347

Bridgstock, R., Grant-Imaru, M., \& McAlpine, A. (2019). Integrating career development learning into the curriculum: Collaboration with the careers service for employability. Journal of Teaching and Learning for Graduate Employability, 10(1), 56-72.

Brown, S. D., \& Ryan Krane, N. E. (2000). Four (or five) sessions and a cloud of dust: Old assumptions and new observations about career counseling. In S. D. Brown \& R. W. Lent (Eds.), Handbook of counseling psychology, (pp. 740-766). New York, NY: Wiley.

Brown, S. D., \& Roche, M. (2016). The outcomes of vocational interventions: Thirty (some) years later. Journal of Career Assessment, 24(1), 26-41. doi: 10.1177/1069072715579666

Choate, J., Green, J., Cran, S., Macaulay, J., \& Etheve, M. (2016). Using a professional development program to enhance undergraduate career development and employability. International Journal of Innovation in Science and Mathematics Education, 24(3), 49-70.

Ciarocco, N. J. (2018). Traditional and new approaches to career preparation through coursework. Teaching of Psychology, 45(1), 32-40. doi:10.1177/0098628317744963

Crawford, J., Cayley, C., Lovibond, P. F., Wilson, P. H., \& Hartley, C. (2011). Percentile norms and accompanying interval estimates from an Australian general adult population sample for self-report mood scales (BAI, BDI, CRSD, CES-D, DASS, DASS-21, STAI-X, STAI-Y, SRDS, and SRAS). Australian Psychologist, 46(1), 3-14. doi: 10.1111/j.1742-9544.2010.00003.x

Deer, L. K., Gohn, K., Kanaya, T. (2018). Anxiety and self-efficacy as sequential mediators in US college students' career preparation. Education and Training, 60(2), 185-197. doi: 10.1108/ET-07-2017-0096

Ferns, S., Smith, C., \& Russell, L. (2014). The impact of work integrated learning on student work readiness. Sydney: Office for Learning and Teaching. [last accessed 2019 Mar 29]. Available from: https://Itr.edu.au/resources/SI11 2139 Smith Report 2014.pdf

Choate, J., Demaria, M., Etheve, M., Cran, S., \& Carroll, D. (2019). A professional development program with an assessed ePortfolio: A practical solution for engaging undergraduates with their career development in large student cohorts. Journal of Teaching and Learning for Graduate Employability, 10(2), 86-103. 
Gedye, S., Fender, E., \& Chalkley, B. (2004). Students' undergraduate expectations and post-graduation experiences of the value of a degree. Journal of Geography in Higher Education, 28(3), 381-396. doi: $10.1080 / 0309826042000286956$

Gillie, S., \& Gillie Isenhour, M. (2003). The educational, social and economic value of informed and considered career decisions. Alexandria, VA: America's Careers Resource Network Association.

Harris K-L. (2007). Why do a science degree? The influences on students choosing to study science in Australia. Centre for the Study of Higher Education: The University of Melbourne. [last accessed 2019 Feb 23]. Available from: https://melbournecshe.unimelb.edu.au/ data/assets/pdf file/0003/1714692/KLHarris 290ct choosingScience.pdf

Hodgson, Y., Waring, J., Flecknoe, S., \& Choate, J. (2015). Selecting for graduate medicine without traditional aptitude testing; Biomedical Science as a pathway to graduate medicine. Student Selection for the Health Professions Conference, Melbourne.

Hughes, D., Bosley, S., Bowes, L. \& Bysshe, S. (2002). The economic benefits of guidance. CeGS Research Report Series No. 3. Derby: Centre for Guidance Studies, University of Derby. Retrieved from:

http://www.derby.ac.uk/media/derbyacuk/contentassets/documents/ehs/icegs/2002HughesD\&SB\&LB\&SBThe-Economic-Benefits.pdf

Jackson, D., \& Wilton, N. (2016). Developing career management competencies among undergraduates and the role of work-integrated learning. Teaching in Higher Education, 21(3), 266-286. doi: 10.1080/13562517.2015.1136281

Kahu, E. R. (2013). Framing student engagement in higher education. Studies in Higher Education, 38(5), 758-773. doi: 10.1080/03075079.2011.598505

Kahu, E. R., \& Nelson, K. (2018). Student engagement in the educational interface: Understanding the mechanisms of student success. Higher Education Research \& Development, 37(1), 58-71. doi: 10.1080/07294360.2017.1344197

Kandiko, C. B., \& Mawer, M. (2013). Student expectations and perceptions of higher education. London: King's Learning Institute.

Larcombe, W., Finch, S., Sore, R., Murray, C. M., Kentish, S., Mulder, R. A., \& Williams, D. A. (2016). Prevalence and socio-demographic correlates of psychological distress among students at an Australian university. Studies in Higher Education, 41(6), 1074-1091. doi: 10.1080/03075079.2014.96607

Lovibond, S. H., \& P. F. Lovibond. (1995). Manual for the depression anxiety stress scales. 2nd ed. Sydney: Psychology Foundation of Australia

Mayston, D. (2002). Evaluating the benefits of career guidance. Derby, UK: Centre for Guidance Studies, University of Derby

Olive, K. E., Kwasigroch, T. E., Wooten, D. J., Lybrand, C., \& Peeples, C. R. (2016). A career exploration program: An effective alternative to the traditional use of faculty advisors. Academic Medicine, 91(11), 1530-1533. doi:10.1097/ACM.0000000000001208

Organisation for Economic Co-operation and Development (OECD) (2018). Education at a Glance 2018: OECD Indicators. Paris: OECD Publishing. doi: 10.1787/eag-2018-en

Perrone, P., \& Vickers, M. (2003). Life after graduation as a "very uncomfortable world": An Australian case study. Education and Training, 45(2), 69-78. doi: 10.1108/00400910310464044

Quality Indicators for Learning and Teaching. (2017). 2016 Graduate Outcomes Survey [Data file]. Retrieved from https://www.qilt.edu.au/about-this-site/graduate-employment

Quality Indicators for Learning and Teaching. (2018). 2017 Graduate Outcomes Survey [Data file]. Retrieved from https://www.qilt.edu.au/about-this-site/graduate-employment

Rosenthal, D. A., Russell, J., \& Thomson, G. (2008). The health and wellbeing of international students at an Australian university. Higher Education, 55(1), 51-67. doi: 10.1007/s10734-006-9037-1

Skatova, A., \& Ferguson, E. (2014). Why do different people choose different university degrees? Motivation and the choice of degree. Frontiers in Psychology, 5, 1244. doi: 10.3389/fpsyg.2014.01244

Tinto, R. (2017). Reflections on student persistence. Student Success, 8(2), 1-8. doi: 10.5204/ssj.v8i2.376

Thomas, J., \& McDaniel, C. (2004). Effectiveness of a required course in career planning for psychology majors. Teaching of Psychology, 31(1), 22-27. doi: 10.1207/s15328023top3101_6

Townes, O., Tang, S., \& Hall, K. (2011). Changing our thinking: Empirical research on law student wellbeing, thinking styles and the law curriculum. Legal Education Review, 21, 149-182.

Choate, J., Demaria, M., Etheve, M., Cran, S., \& Carroll, D. (2019). A professional development program with an assessed ePortfolio: A practical solution for engaging undergraduates with their career development in large student cohorts. Journal of Teaching and Learning for Graduate Employability, 10(2), 86-103. 
Walker, J. W. \& Peterson, G. W. (2012). Career Thoughts, Indecision, and Depression: Implications for Mental Health Assessment in Career Counseling. Journal of Career Assessment, 20(4), 497-506. doi: $10.1177 / 1069072712450010$

Watts, A. G., \& Hawthorn, R. (1992). Careers education and the curriculum in higher education. UK Higher Education Academy. Careers Research and Advisory Centre.

Whiston, S. C., Li, Y., Goodrich Mitts, N., \& Wright, L. (2017). Effectiveness of career choice interventions: A metaanalytic replication and extension. Journal of Vocational Behavior, 100, 175-184. doi:10.1016/j.jvb.2017.03.010

Whiston, S. C., Sexton, T. L., \& Lasoff, D. L. (1998). Career-intervention outcome: A replication and extension of Oliver and Spokane (1988). Journal of Counseling Psychology, 45(2), 150-165. doi: 10.1037/0022-0167.45.2.150

Whiston, S. C., Brecheisen, B. K., \& Stephens, J. (2003). Does treatment modality affect career counseling effectiveness? Journal of Vocational Behavior, 62(3), 390-410. doi:10.1016/S0001-8791(02)00050-7

Whiston, S. C., \& James, B. N. (2013). Promotion of career choices. In S. D. Brown \& R. W. Lent (Eds.), Career development and counseling: Putting theory and research to work, (2nd ed., pp. 565-594). Hoboken, NJ: Wiley.

Zunker, V. (2008). Career, work, and mental health: Integrating career and personal counseling. Sage Books. doi: $10.4135 / 9781452275086$

Choate, J., Demaria, M., Etheve, M., Cran, S., \& Carroll, D. (2019). A professional development program with an assessed ePortfolio: A practical solution for engaging undergraduates with their career development in large student cohorts. Journal of Teaching and Learning for Graduate Employability, 10(2), 86-103. 